\title{
A LINGUAGEM DOS SÍMBOLOS NO CONTEXTO DA MIGRAÇÃO
}

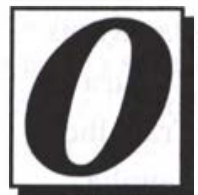

processo migratório implica, invariavelmente, além da transposição de fronteiras geográficas, na inserção em uma nova ordem sócio cultural, a qual é, em geral, marcada por tensões e estranhamentos que acabam por incidir na dinâmica cultural do grupo dos emigrados, conferindo Ihe especificidades e significações.

A inserção dos migrantes num novo contexto, porém, não significa a perda ou simplesmente a fusão da sua cultura original; esta tende a simplificar se e a condensar-se em alguns traços, que passam a ser diacríticos, ou seja, distintivos para o grupo que os veicula, conferindo-lhe maior visibilidade.

É nesse contexto contrastivo que elementos da cultura material, formas linguisticas, rituais, tradições, festas, entre outros, ganham relevância, evocando, muitas vezes, vários significados, dependendo da conjuntura em que são veiculados. Nessa perspectiva, linguagens e símbolos podem estar evocando ao mesmo tempo várias coisas, entre elas uma nova forma de pertencimento, como éo caso do uso da língua portuguesa no espaço público entre os imigrantes retornados em Luanda, ou ainda alimentos específicos, como o vinho a polenta para as gerações de descendentes de italianos no sul do Brasil, para os quais estes representam uma forma de manter o vínculo com a tradição cultural de seus pais. O alimento e a bebida podem ser também expressão da reafirmação de identidades, regionais, nacionais, étnicas ou culturais, as quais são veiculadas em rituais religiosos, como é o caso da ch'alla (libação à Mãe Terra) entre os bolivianos em São Paulo, ou do tradicional Ramadán, entre os árabes em Porto Alegre. Símbolos, como o véu usado pelas mulheres muçulmanas no bairro do Brás em São Paulo, podem ser, ainda, uma linguagem encontrada pelas novas gerações para ressignificar identidades, que por força de uma conjuntura histórica foram preteridas pela primeira geração e que, agora, são evocadas por elas como um sinal diacrítico frente a uma tradição cultural cristã presente na sociedade brasileira.

Assim, como uma linguagem distintiva, os simbolos podem estar dizendo várias coisas ao mesmo tempo sobre quem os veicula, bem como podem ser tomados também como uma forma de diálogo com o novo contexto que os recebe, diálogo este marcado, não raras vezes, por tensões e ambiguidades. Uma rápida incursão no mundo dos símbolos, porém, veiculados em contextos específicos, é o que propõe aos seus leitores este número da Travessia.

$$
\text { Sidney Antonio da Silva }
$$

